\title{
Türkiye'de Organik Ekoturizm Çiftlikleri Üzerine Bir Araştırma ${ }^{1}$
}

\author{
Saida Ahmadova ${ }^{a^{*}}$, Orhan Akova ${ }^{b}$ \\ ${ }^{a}$ İstanbul Üniversitesi, İşletme Fakültesi, Pazarlama Anabilim Dalı, İstanbul \\ 'ístanbul Üniversitesi, İktisat Fakültesi, Turizm İşletmeciliği Bölümü, İstanbul
}

\begin{abstract}
Öz
Son yillarda gerek dünyada gerek Türkiye'de turistlerin turizm eğilimleri incelendiğinde turizm hareketlerine katılanların turizmden beklentilerinin değişmekte olduğu görülmektedir. Insanlar kalabalık ve alışlmış turizm merkezlerinden uzaklaşarak alternatif turizm türlerinden biri olan ekoturizme gittikçe daha fazla katılmaktadırlar. Çiftlik turizmi, gelen ziyaretçilerin hem tarım ve hayvancilık, hem de çeşitli ekoturizm faaliyetlerini birlikte kullanabilmesini sağlayan, bunun yanı sıra yöre halkına ekonomik anlamda ek gelir kazandıran, aynı zamanda bölgenin kültürel anlamda tanıtılmasına da katkıda bulunan bir turizm çeşididir. Çevreye geri dönüşü olmayan zararlar veren kitle turizminin aksine sürdürülebilir ilkeler doğrultusunda gelişen çiftlik turizminin Türkiye'de de uygulama alanları genişlemektedir. Bu çalışmanın amacı, Buğday Ekolojik Yaşamı Destekleme Derneği'nin TaTuTa projesi kapsamında Türkiye'nin farkh bölgelerinde faaliyet gösteren organik ekoturizm çiftliklerinin turizm işletmeciliği açısından incelenmesidir. Bu kapsamda bu çiftliklerin müşteri profilleri, sunulan ürün özellikleri, yönetim ve organizasyon biçimleri, pazarlama stratejileri, insan kaynakları yönetimi gibi turizm işletmeciliği uygulamaları araştırılmıştır. Bu doğrultuda çiftliklere anket çalışması uygulanarak çiftlik yöneticilerinin fikir ve düşünceleri incelenmiş, ortaya çıkan bulgular tartışılmıştır. Araştırmada elde edilen bulgular doğrultusunda çiftliklerin müşteri profillerinin çoğunlukla gönüllü, stajyer, yarı gönüllü, aynı zamanda belirli bir ücret karşıllğında gelen yabancı ve yerli misafirler olduğu sonucuna varılmıştır. Çiftliklerin tanıtımı ve pazarlama faaliyetleri genelde Buğday Derneği tarafından gerçekleştirilse de organik ürün pazarlaması yapan çiftlikler aynı zamanda bu ürünlerin üretimi, tanıtımı, satışı ile de uğraşmaktadır. Çiftliklerin büyük bir kısmında insan kaynakları yönetimi departmanı bulunmamakta, bu görevi çiftlik sahibi veya yöneticisi olan bir kişi üstlenmektedir. Bu çalışmada ayrıca elde edilen bulgular tartışılarak yerel ve merkezi hükümetlere, çiftlik yöneticileri ve araştırmacılara öneriler sunulmuştur.
\end{abstract}

Anahtar kelimeler: Alternatif turizm, Ekoturizm, Çiftlik turizmi, Organik Ekoturizm Çiftlikler.

\section{A Research on Organic Ecotourism Farms in Turkey}

\section{Abstract}

In recent years' when tourism trends examined both in the world and in Turkey, it is noticed that, the expectations of the tourists have changed. People have moved away from crowded, usual tourism centers to rural areas and participated in ecotourism activities which is one of the alternative types of tourism. Farm tourism is a type of tourism which allows visitors to use both agriculture and livestock and various ecotourism activities together, as well as it brings extra income to the local people of the region, at the same time it contributes the promotion of the region. Contrary to the mass tourism which has irreversible environmental damages, farm tourism's

\footnotetext{
${ }^{1}$ Bu makale Saida Ahmadova'nın “Türkiye'de Organik Ekoturizm Çiftlikleri Üzerine Bir Araştırma” adlı yüksek lisans tezinden hazırlanmıştır.
}

*Yazışma Adresi.Email. saida.akhmedova@yahoo.com 
implementation areas have been expanding in Turkey. The aim of this paper is to examine organic ecotourism farms of Wheat Ecological Life Support Association' of TaTuTa project operating in different regions of Turkey in the context of tourism management. In this context, tourism management applications such as customer profiles, the features of product, managerial and organizational styles, marketing strategies, human resources management were analyzed. Fort his purpose farm managers' opinions and ideas were examined by applying a questionnaire and findings were discussed. It is concluded that the guests visiting farms are mostly volunteers, interns, semivoluntaries, also they are domestic and foreign visitors who pay for accommodation. Although promotion and marketing activities of farms are conducted by the Wheat Marketing Association, farms also market their organic products, advertise and sell these products. There is no human resources department in the farms, this task is provided by the owner or the manager of the farm. Besides in this paper after dicussion of the findings, some suggestions are offered for the local and central authorities, farm managers and researchers.

Keywords: Alternative Tourism, Ecotourism, Farm Tourism, Organic Ecotourism Farms.

\section{Gírìș}

Son yıllarda tüketicilerin ürün ve hizmet taleplerindeki farklılıklar, bireylerin eğitim ve kültür düzeylerinin yükselmesi, sosyal ve demografik yapıdaki değişimler turizm sektöründe de etkisini göstermiştir. Daha yüksek eğitim düzeyine sahip, çevreye ve doğaya duyarlı, sağlıklı yaşam ve gida tüketimi konusunda daha bilinçli hale gelen turistler doğaya, şehir hayatından, gürültüden, kargaşadan uzak kırsal alanlara yönelmektedirler.

Ekoturizmin gelişimi, doğal ve kültürel çevreyi anlayan, ekosistemin bütünlügünü koruyan ve aynı zamanda yerel halk için faydalı olan doğal kaynakların korunduğu, yerel halk için ekonomik fırsatlar yaratan doğal alanlara yapılan anlamlı seyahatin bir parçası olarak çiftlik turizminin popülarite kazanmasına sebep olmuştur. Ekoturizm kaynakları açısından zengin olan Türkiye'nin genel olarak çiftlik turizmi potansiyelini ortaya koyacak çalışmalar çok fazla değildir.

Bu çalışmada Buğday Ekolojik Yaşamı Destekleme Derneği'nin TaTuTa projesi kapsamında Türkiye'nin farklı bölgelerinde faaliyet gösteren organik ekoturizm çiftliklerinin turizm işletmeciliği faaliyetleri incelenmiştir. Bu kapsamda çiftliklerin müşteri profilleri, sunulan ürünün özellikleri, yönetim ve organizasyon biçimleri, pazarlama stratejileri, insan kaynakları yönetimi gibi turizm işletmeciliği uygulamaları araştırılmıştır. Bu doğrultuda çiftlik yöneticilerinin fikir ve düşüncelerini ortaya koymak amacıyla bu araştırmada anket çalışması yapılmış ve bulgular tartışılmıştır. Daha önce bu konuda yapılan çalışmalardan farklı olarak çalışmada bir bölgede değil, tüm Türkiye' de faaliyet gösteren "Doğa Dostu” profilli TaTuTa çiftlikleri incelenmiştir. Bu bağlamda çalışma bu açıdan önem taşımakta olup çalışmanın Tükiye genelinde daha geniş kapsamlı çalışmalara 1şık tutacağı beklenmektedir.

Çalışmanın literatür kısmınds ekoturizm kavramı ve gelişim süreci, çiftlik turizmi kavramı ve gelişim süreci, çiftlik turizminin özellikleri ve bu kapsamda gerçekleştirilen faaliyetler açıklanmıştır. Ayrıca organik tarım faaliyetleri ile çiftlik turizmi ve organik ekoturizm çiftlikleri hakkında bilgiler verilmiştir. Çalışmanın 
ampirik kısmında ise Türkiye'de çiftlik turizmi kapsamında faaliyet gösteren, TaTuTa çiftliklerinde yapılan araştırmanın bulguları paylaşılmıştır.

\section{LITERATÜR}

Turizm sektörünün gelişmeye başladığı ilk yıllarda turizm ekonomik gelişme ve istihdam olanakları gibi ekonomik faydalar açısından ele alınmış ancak zamanla olumsuz sosyal, kültürel ve çevrsel etkiler görülmeye başlanmıştır. Misafirler için yapılan oteller, yollar ve diğer sosyal tesislerden dolayı yerel topluluklar yerlerinden edilmiş ve yaşam tarzları değişime uğramıştır. Turist sayısının gittikçe artması doğal hayatı ve hayvan yaşamını tehdit etmeye başlamıştır.

Alternatif turizmin çeşitlerinden biri olarak çiftlik turizmi, gittikçe büyüyen bir turizm türüdür. Kırsal bölgelere seyahat etmeye cesaret eden turist sayılarının giderek artması ve tarım turizmi ile ilgili sınırlı sayıda araştırma olması, bu alanda ampirik incelemeye ihtiyaç olduğunu göstermektedir (Oppermann, 1995: 65).

Son 50 yılda endüstrileşmiş ülkelerde ekonomik, politik, sosyal ve teknolojik gelişmeler sonucunda kırsal bölgelerde önemli yapısal değişiklikler yaşanmıştır. Bu yapısal değişimin bir sonucu olarak - kırsal alanlarda ekonomik yapı da değişime uğramış ve kırsal kalkınmanın sağlanması için yeni modeller geliştirilmiştir. Bu doğrultuda bugün çiftlik turizmi büyük önem taşımakta, tarımsal çeşitlendirmenin ve yerel kalkınmanın tamamlayıcı bir aracı olarak görülmektedir (Gössling \& Mattsson, 2002: 17).

80'lerin başından beri insanların yoğun tarım faaliyetlerinin sebep olduğu tehlikelerin farkına varması nedeniyle sürdürülebilir tarımsal kalkınma bağlamında ekologlar tarafından desteklenen, kimyasal gübrelerin ve sentetik pestisidlerin kullanımını tamamen ortadan kaldıran "organik" ya da "biyolojik"- tarım modeli, nispeten küçük alanlarda uygulanmaya başlanmıştır. Organik ürünler, insanların sağlıklı yaşamasına katkıda bulunur, sentetik pestisidlere ve kimyasal gübrelere karşı su kaynaklarının korunmasını sağlar, çiftçilerin mesleki zorluklarının üstesinden gelmeleri ve kırsal kalkınma için çözümler sunar; aynı zamanda, gelecek nesillere sağlıklı bir gelecek sağlar (Sima, 2007: 25).

Kitle turizminin yıkıcı olumsuz etkileri; turistin doğal çevrenin korunmasına yönelik olarak gösterdiği hassasiyet ve turistlerin değişen seyahat motivasyon ve beklentileri turizm pazarını da değiştirmiş ve çeşitlendirmiş, 1990'lı yıllardan itibaren ekoturizm, kırsal turizm, toplum temelli turizm, doğa turizmi vb. alternatif turizm türlerinin gelişmesini sağlamıştır. Ekoturizm, kırsal ve kültürel turizmin unsurlarını içermekte ve hassas doğal ve kültürel alanlarda geliştirilebilecek en uygun turizm türü olarak ifade edilmektedir. Kontrolsüz gelişen kitlesel turizm hareketinin çevre ve toplum üzerindeki olumsuz etkileri karşısında ekoturizm, sürdürülebilir gelişmenin sağlanmasında önemli bir araç olarak görülmektedir (Kuter \& Ünal, 2009: 146).

Ekoturizm çeşitli kıstaslara göre gruplandırılır. Bu kıstaslar, turizmde kullanılan araçlar (bisiklet, balon, rafting, at), gidilen yerin doğası (dağ, yayla, mağara), yapılan etkinliğin özelliği (akarsu, av, bilim, trekking) gibi çeşitlilik göstermektedir. 
Ekoturizm kapsamında yapılan başlıca ekoturizm etkinlikleri şu şekilde sıralanabilir: kuş gözlemciliği, yabanı hayatı gözlemleme, yayla, mağara, av, bisiklet, doğa yürüyüşü (trekking), sualtı dalış, atlı doğa, olta balıkçılığı, çiftlik turizmi vb. (Bulut \& Akpinar, 2010: 1580).

Tarım ya da hayvan üretme çiftliklerinde tatil yapma North Dakota'da 19. yüzyılın sonlarında başlamıştır. İlk çiftlikler 1880 yılında işletilmeye başlanmıştır. 1949 'da yayımlanan ilk çiftlik tatili broşürlerinde turistler tarafından kabul gören çiftlik tatili imkânları listelenmiştir (Ersöz \& Bozkurt, 2015).

Çiftlik turizmi, kırsal turizm çerçevesinde güçlü bir çevre unsuru ile birlikte ele alınan bir turizm şeklidir. Çiftlik turizmi ile ilgili birçok tanım bulunmaktadır fakat genel olarak çiftlik sahibi ile birlikte çiftlik işlerini yapabilme olanağı olan çiftliklerde gerçekleştirilen turistik faaliyetler temeline dayanmaktadır (Ersöz \& Bozkurt, 2015: 3).

Çiftlik turizmi, kırsal bölgelerin özellikle de yıl boyunca turizm faaliyetleri için elverişli koşulları olan yerlerin geliştirilmesinde önemli bir araçtır. Çiftlik turizminin bazı temel şartları karşılaması gerekmektedir (Cut-Lupulescu, Dincu, \& Borlovan, 2014):

- Tarım sistemlerinde ortaya çıkan sorunlara ve kırsal kesimin karşılaştı̆̆ krizlere karşı koyabilmeleri için yerel halka ek gelir sağlamak;

- Turistik çekiciliği olan ürünleri ve yerel hizmet arzını artırarak ekonomik faaliyetlerin çeşitlendirilmesini sağlamak;

- Ekolojik sistemler, sosyo-ekonomik ve sosyo-kültürel gelişmeler arasında bir denge oluşturmak ve gelişim sürecini, dolayısıyla değişimi desteklemek;

- Dayanışma ve sosyal uyum faktörü olarak kültürel alışverişi desteklemek, yerel halk ve ziyaretçiler için yaşam koşullarının iyileştirilmesi amacıyla belirlenmiş bölgesel politikaların uygulanmasına yardımcı olmak, az gelişmiş bölgelerde ekonomik faaliyetlerin rekabet edebilirliğini arttırmak, gerekli ekipman ve altyapının karşılanmasını sağlamak.

Çiftlik turizmi arzı, politikalara, turistik arza, turistik aktivitelerin gerçekleştirildiği bölgenin coğrafi özelliklerine ve çiftlik sahibinin yaratıcılığına göre değişir. Turistik ürünün temelinde tarımsal üretim ve geleneksel yaşam tarzı (yemek, sağlık, el sanatları, ev idaresi ve kat hizmetleri) bulunmaktadır. Black ve ar. (2001) ABD'deki çiftlik turizmi kapsamındaki aktiviteleri altı grupta sınıflandırmıştır:

1. Gecelik konaklamalar: Konaklama ve Kamp, Oda ve Kahvaltı, Kamp siteleri, Gençlik kampı, Çiftlikte yaşam, hayvan besleme, meyve/sebze toplama, Günlük gezi/piknik için kulübe kiralama, Dügünler, davetler, balayılar.

2. Özel etkinlikler ve festivaller: Müzik festivalleri, Hasat festivali.

3. Çiftlik dışı: Çiftçi pazarı, Fuarlar, Yol stantları.

4. Rekreasyon faaliyetleri ve etkinlikler: Ücretli balık avlama, Bisiklet sürme, Binicilik, Kuş gözlemciliği, Yürüyüş, Kaya tırmanışı.

5. Taze ve katma değerli ürünler: Kendi meyveni/sebzeni yetiştirme, Çiftlikte konserve gıdaların satışı, Bitkisel/organik ürünlerin satışı. 
6. Gençlik ve/veya yetişkin eğitimi: Organize turlar, Tarımsal eğitim programları, Doğa eğitim turları, Şarap, bal, el sanatları yapımı gibi gösteriler/nümayiş̧ler.

\section{Türkiye'de Organik Ekoturizm Çiftlikleri}

Tükiye'de de çiftlik turizmi kapsamında faaliyet gösteren Ekoturizm çiftlikleri, “Ekolojik Çiftliklerde Tarım Turizmi ve Gönüllü Bilgi, Tecrübe Takası" olarak bilinen ve kısa adı "TaTuTa" (Tarım-Turizm-Takas) olan proje ile faaliyetlerini sürdürmektedir. 2004'ten beri faaliyet gösteren TaTuTa projesi, dünya çapında yaklaşık 100 ülkede, 11 binin üzerinde ekolojik çiftliğin üye olduğu WWOOF (Worldwide Opportunities on Organic Farms / Organik Çiftliklerde Uluslararası Fırsatlar) ağının da Türkiye temsilcisidir. TaTuTa projesi, ekolojik tarımla geçinen çiftçi ailelere maddi ve manevi destek vermek, ekolojik tarıma katkıda bulunmak ve sürdürülebilirliğini sağlamak amacıyla kurulmuştur. Projede, ekolojik üretimin teknik, pazarlama, sosyal, çevresel vb. boyutlarında bilgi/ilgi sahibi kişiler, çiftlik ve işletmelerde bilgi, deneyim ve/veya işgüçlerini paylaşırken yiyecek, içecek ve barınma ihtiyaçları çiftlik tarafından karşılanmaktadır. Bu proje kapsamında gönüllü veya konuk statüsünde ülkenin çeşitli bölgelerinden ya da, farklı ülkelerden gelen misafirler çiftlikleri ziyaret etmektedirler. Gönüllü olarak gelen misafirler, herhangi bir ücret ödemeksizin ilgi, tecrübe veya yarattıkları işgücü vasıtasıyla ev sahibi çiftçilere işlerinde yardımcı olmakta, bunun karşılığında da çiftçi misafire ücretsiz kalacak yer, yemek sunmaktadır. Konuk statüsünde çiftliği ziyaret eden misafirlerin ise çiftlikte çalışma zorunluluğu bulunmamaktadır (Çinko, 2013).

Türkiye'de çiftlik turizmi kapsamında faaliyet gösteren ekoturizm çiftliklerinin 2013 yılında bölgelere göre dağılımı Tablo 1'de verilmektedir

Tablo 1. Türkiye'deki Ekoturizm Çiftliklerinin Bölgelere Göre Dağılımı (2013).

\begin{tabular}{|c|c|}
\hline Bölgeler & Sayı \\
\hline Akdeniz & 12 \\
\hline Karadeniz & 28 \\
\hline Doğu Anadolu & 6 \\
\hline İç Anadolu & 6 \\
\hline GüneydoğuAnadolu & 2 \\
\hline Ege & 19 \\
\hline Marmara & 8 \\
\hline Toplam & $\mathbf{8 1}$ \\
\hline
\end{tabular}

Kaynak: (Civelek, Dalgın, \& Çeken, 2013).

Buğday Derneği'nin yetkilisi A. Berkay Atik'in verdiği bilgiye göre toplam 81 ekoturizm çiftliğine ek olarak 2014 yılında 10 çiftlik daha faaliyete başlamıştır (Ahmadova, 2015). 


\section{METODOLOJI}

$\mathrm{Bu}$ çalışma, Buğday Ekolojik Yaşamı Destekleme Derneği TaTuTa projesi kapsamındaki çiftliklerin müşteri profilleri, sunulan ürünlerin özellikleri, yönetim ve organizasyon biçimleri, pazarlama stratejileri, insan kaynakları yönetimi gibi turizm işletmeciliği uygulamalarının belirlenmesini amaçlamaktadır.

Çalışmada veri toplama aracı olarak anket tekniği kullanılmıştır. Anket soruları yerli ve yabancı literatürden yararlanılarak yazarlar tarafından hazırlanmıştır. Anket çalışması 2015 yılı ocak-şubat-nisan aylarında uygulanmıştır. Uzaklık ve maliyet nedeniyle anketler e-posta yolu ile dağıtılmıştır. E-postalarına ulaşılamayan çiftliklerin bazıları ile telefon görüşmeleri yapılarak anket soruları telefon görüşmesi sırasında sorulmuştur. 30 sorudan oluşan ankette işletme sahiplerine ve yöneticilerine çiftliklerin kapasiteleri, konumları, kuruluş amaçları, sundukları turizm hizmetleri, gerçekleştirdikleri ekoturizm faaliyetleriyle ilgili sorular ile çiftliklerin pazarlama faaliyetleri, halkla ilişkiler, reklam, tanıtım çalışmaları, personel yönetimi, insan kaynakları çalışmaları kapsamında uyguladıkları yöntemlerle ilgili sorular sorulmuştur. Ankette birden fazla şık işaretlenebilen 19 çoktan seçmeli sorunun yanı sıra, katılımcıların kişisel düşüncelerini yazmaları için 7 açık uçlu soru sorulmuştur. Anket çalışması kapsamında Marmara bölgesinde 1, Karadeniz bölgesinde 4, Ege bölgesinde 6, Akdeniz Bölgesinde 2, Doğu Anadolu Bölgesinde 2, İç Anadolu Bölgesinde 2 olmak üzere toplam 17 çiftlik ile görüşülmüştür.

Araştırma bulgularının analizi için içerik analizi kullanılmıştır. İçerik analizi ile metnin içeriğindeki temel öğeler sistematik olarak kodlanarak Office programında kelime saydırma işlemi yardımıyla tekrar edilen kelimelerin bulunmasıyla araştırmanın nicel olarak da incelenmesi sağlanmaya çalışılmıştır (Sünnetçioğlu \& Yilmaz, 2015: 102).

Araştırmanın sınırlılıklarından biri, araştırmanın yapıldığı "doğa dostu" profilli çiftlik sayısının 22 olmasına rağmen, çiftliklerin hepsinin anketi cevaplamamış olmalarıdır. Öngörüşme yapılan 22 çiftlikten sadece 17'si araştırmaya katılmıştır. Bazılarının internete erişim sorunlarından, bazılarının web sitelerinin olmamasından dolayı, bazıları ile ise defalarca telefon görüşmeleri yapılmasına rağmen (belirttikleri üzere) aşırı yoğun olmaları sebebiyle ankete cevap verememişlerdir.

\section{BULGULAR}

Anket bulguları tablolar halinde özetlenmiş ve içerik analizi yapılarak yorumlanmıştır.

\section{Gerçekleştirilen Gönüllü İşler}

TaTuTa projesi kapsamında farklı özelliklere sahip çiftlikler faaliyet göstermesine karşın bu çalışma, organik tarım odaklı turizm faaliyetinde bulunan çiftlik-otellere (toplam 22 çiftlik) yönelik olduğundan anket çalışması sadece organik ekoturizm çiftliklerini kapsamaktadır. Anketin uygulandığ doğrultusunda yapılan faaliyetler işletmelerin konumuna ve özelliklerine göre farklılık göstermektedir. Bu faaliyetler; ürün ekimi ve bakımı, hayvan bakımı, geleneksel el 
sanatları uygulamaları, sertifikalı organik tarım, ekolojik yaşam eğitimleri gibi faaliyetleri kapsamaktadır. Bunun yanısıra çiftlikler arasında sertifikalı organik ürünler yetiştiren ekolojik oteller ile yoga, doğal yaşam ve tarımsal faaliyetlerden gelir elde eden çiftlik-oteller de bulunmaktadır.

Bunun yanı sıra çiftlikler arasında sertifikalı organik ürünler yetiştiren ekolojik oteller ile yoga, doğal yaşam ve tarımsal faaliyetlerden gelir elde eden çiftlik-oteller de bulunmaktadır.

\section{Gerçekleştirilen Ziyaret Türleri}

Ziyaret türleri, çiftliklerin kuruluş amaçları ve faaliyet türlerine göre farklılık göstermektedir. Örneğin, yoga, doğal yaşam, geleneksel el sanatları ile uğraşan Yoga Evi'nin ziyaretçi kabul etmesinin sebebi bundan maddi kazanç elde etmesidir. Ancak organik tarım, organik ürün satışı ve pazarlamasını gerçekleştiren diğer çiftlikler hem gönüllü, yarı gönüllü ve stajyer, hem de misafir ziyaretlerine ev sahipliği yaptıklarını belirtmişlerdir.

TaTuTa çiftliklerinde gerçekleştirilen faaliyetler, literatürde çitlik turizmi kapsamında misafirlere sunulan aktivitelerle karşılaştırıldığında birtakım farklılıklar göze çarpmaktadır. Bu çiftliklerin bir kısmı TaTuTa çiftliklerinden farklı olarak müzik ve hasat festivalleri, çeşitli davetler gibi özel etkinlikler ile çiftlik dışı çeşitli faaliyetlerde bulunmaktadırlar.

\section{Yılı Doluluk Oranları}

Tablo 2'de çiftliklerin 2014 yılı doluluk oranları gösterilmiştir. Analiz sonucunda çiftliklerin doluluk oranlarının ortalama $\% 60$ civarında olduğu görülmektedir. Ziyaretler çiftliklerde gerçekleştirilen aktivitelere, sunulan hizmetlere göre farklılık gösterse de turizmin mevsimlik özelliğinin etkisi çiftliklerde de görülmektedir. Çiftlik ziyaretleri genel olarak Nisan-Mayıs aylarından başlayarak Eylül-Ekim aylarına kadar devam etmektedir. 
Tablo 2. Çiftliklerin 2014 yılı ortalama doluluk oranları

\begin{tabular}{|c|c|c|}
\hline Çiftlikler & $\begin{array}{c}\text { Çiftlik } \\
\text { Sayısı } \\
\text { (n) }\end{array}$ & Yüzde (\%) \\
\hline Ali Koçak Çiftliği (Doğu Anadolu) & 1 & 20 \\
\hline Beypazarı Doğa evi (İç Anadolu) & 1 & 60 \\
\hline Ayşe ve Cengiz Genç Çiftliği (Ege) & 1 & 60 \\
\hline Ekodanitap Çiftliği(Karadeniz) & 1 & 90 \\
\hline Gürsel Tonbul (Ege) & 1 & 75 \\
\hline Hindiba Pansiyon (Karadeniz) & 1 & 65 \\
\hline Kapor Çiftliği (İç Anadolu) & 1 & 60 \\
\hline Kaş Eco-Art Farm (Akdeniz) & 1 & 60 \\
\hline Knidia Çiftliği (Ege) & 1 & 60 \\
\hline Nar Çiftliği (Marmara) & 1 & 60 \\
\hline Pastoral Vadi (Ege) & 1 & 60 \\
\hline Rasayana Çiftliği (Akdeniz) & 1 & 40 \\
\hline Sardunya Çiftliği (Ege) & 1 & 40 \\
\hline Turan Farm (Doğu Anadolu) & 1 & $\begin{array}{l}2014 \text { yılında otel } \\
\text { bölümü restore } \\
\text { edilmiştir. }\end{array}$ \\
\hline Yarışkaşı Konağı (Karadeniz) & 1 & 65 \\
\hline Yoga Evi (Marmara) & 1 & 50 \\
\hline Yonca Lodge (Ege) & 1 & 60 \\
\hline Ortalama Doluluk & 17 & 58 \\
\hline
\end{tabular}

\section{Müşteri Profili}

Çiftlik yöneticilerinden elde edilen bulgular ve Buğday Ekolojik Yaşamı Destekleme Derneği yetkilisi Ahmet Berkay Atik'ten elde edilen bilgiler çiftlik ziyaretçilerinin önceki yıllarda daha çok yabancılardan oluştuğunu ancak son yıllarda yerli turistlerin de çiftliklere olan ilgilerinin arttığını göstermektedir. Çiftlikleri ziyaret eden yabancı ve yerli turistler genel olarak ortak özelliklere sahiptir; klasik tatil anlayışından farklı olarak benzersiz deneyimler yaşamak isteyenler veya doğa dostu, sosyal sorumluluk projesiyle çiftlik işlerine katkıda bulunmayı amaçlayanlar, ücret ödeyerek çiftlikte konaklayanlar veya gönüllü ziyaretçiler vb.

\section{Misafir Bilgisi Elde Etme Yöntemleri}

Tablo 3'te de görüldüğü üzere çiftliklerin çoğu misafir bilgi kaynağı olarak daha önceki tecrübelerinden yararlanmaktadır. Bu, uygulanması kolay bir yöntem olsa da, işletmenin güvenilir bilgilere ulaşıp ulaşamayacağı belirsizdir. Çiftliklerin bir kısmı bilgi elde etmek için bu amaçla yapılmış istatistiklerden yararlanmakta ve acentelerle işbirliği yapmaktadır. Genellikle, çiftlik yöneticilerinin büyük çoğunluğu, ziyaretçilerin kişisel adres ve iletişim bilgilerinin kaydını tuttuklarını belirtmekte, bazıları da bu bilgilerin yanı sıra misafirlerin tercih nedenleri, beğenileri gibi bilgileri de kaydetmektedir. Çiftliklerin bir otel işletmesi gibi bu bilgilere önem vermesi ve kaydını tutması, çiftliklerin sadece tarımla uğraşan ve gönüllü bilgi takasında bulunan küçük 
bir köy evi veya çiftlik-otel olmadıklarını aynı zamanda, kurumsal bir işletme olma yolunda ilerlediklerini de göstermektedir.

Tablo 3. Misafir Bilgisi Elde Etme Yöntemleri

\begin{tabular}{|l|c|}
\hline \multicolumn{1}{|c|}{ YÖNTEMLER } & n \\
\hline $\begin{array}{l}\text { Daha önceki tecrübelerden yararlanarak tahminde } \\
\text { bulunmak }\end{array}$ & 9 \\
\hline Yapılmış istatistiklerden yararlanmak & 2 \\
\hline Acenteler ile işbirliği yapmak & - \\
\hline Yukarıdaki araçların hepsini birlikte kullanmak & 6 \\
\hline TOPLAM & 17 \\
\hline
\end{tabular}

\section{Veri tabanı Oluşturma Amaçları}

Çiftlikler, veri tabanı oluşturmak amacıyla misafirlerle iletişim kurmakta ve misafirler için uygun programlar sunmaktadırlar. Bu amaçla faturalama işlemleri, yeni fikir veya ürün geliştirme, müşteri profilini oluşturma gibi faaliyetlerde bulunmaktadırlar. Verilen yanıtlar incelendiğinde, çiftlikler için misafirlerle iletişim kurmak ve onlar için uygun programlar hazırlamak, misafirin gelecek ziyaretleri için bu faaliyetleri daha çok geliştirmenin daha önemli olduğu görülmektedir.

\section{Çiftliği Ziyaret Eden Misafirlere Yönelik Pazarlama Stratejileri}

Çiftliklerde kullanılan reklam araçları çoğunlukla broşürler, fuarlar, web siteleri ayrıca acentalarla yapılan işbirliğidir. Zaman zaman çeşitli web sitelerinde TaTuTa projesi, bu proje kapsamında çiftliklerde görülen işler, çiftlik turizminin Türkiye'de giderek artan öneminden bahsedilmektedir. Ayrıca, yıl boyunca gerçekleştirilen organik ürün fuarlarında yabancı markalarla birlikte, Türkiye'de organik tarımsal üretimle uğraşan bazı çiftliklerin broşürlerini de görmek mümkündür (örneğin, Nar Eğitim ve Organik Tarım Çiftliği - Nar Organik Doğal Ürünler, Gürsel Tonbul Çiftliği -Yerlim Organik Ürünleri v.b).

Çiftliklerdeki konaklama fiyatları çiftliklerin sitelerinde kalacak kişi veya yatak sayısına göre belirtilmektedir. Çiftlikler genellikle, bir dağıtım kanalı olarak internetten yararlanmaktadırlar. Çiftliklerin tamamının web siteleri yoktur. Internet sitesi olan çiftliklerin büyük bir kısmı, internet sitelerinde arazi ve tesisin konumu, çiftlikte gerçekleştirilen faaliyet türleri, çiftlik binalarının özellikleri ve sunulan hizmetler ile ilgili fotoğrafları kullanarak, ayrıca çiftliklerde daha önce konaklayan misafirlerin fikir ve düşüncelerine yer vererek çiftlik hakkında bilgi vermektedirler. Bunun yanısıra web sitelerinde rezervasyon sistemine sahip olan çiftlikler, ziyaretçilerine internet üzerinden rezervasyon yapabilme olanağı sağlamaktadırlar.

Çiftliklerin acentalarla bireysel işbirliği olmasa da, Buğday Derneği'nin GençTur'la yaptı̆̆ı anlaşma ile çiftliklerin misafirlere, ziyaretçilere tanıtımı yapılmaktadır. Çiftlik ziyaretinde bulunmak isteyenler, GençTur'a başvurarak bilgi, destek alabilmekte ve rezervasyon yaptırabilmektedir. 


\section{İzlenen Tutundurma Stratejisi}

Çiftikte izlenen tutundurma stratejileriyle ilgili olarak çiftlik yöneticilerinin verdiği yanıtlar Tablo 4'te gösterilmektedir. Çiftliklerin bir kısmında her türlü reklam, satış, tanıtım, halkla ilişkiler vb. faaliyetler gerçekleştirilmektedir., Bazı çiftlikler ise müşteri kayıtlarını inceleyerek müşteri kitlesine uygun tanıtım yöntemleri kullanmaktadır. Herhangi bir tutundurma stratejisi uygulamayan çiftlikler de mevcuttur. Genelde bu çiftliklerin web sitesi de bulunmamaktadır. Çiftliklerin uyguladıkları tutundurma stratejileri yanı sıra Buğday Ekolojik Yaşamı Destekleme Derneği yetkilisi Berkay Atik'in belirttiği üzere, Buğday Derneği iletişim kanallarında (resmi site, sosyal medya, üyelere gönderilen "Ekoljik Yaşam Rehberi" adlı dergi) dönemsel olarak tanıtımlar yapılmaktadır. Bunun yanısıra, zaman zaman çeşitli radyo, gazete ve dergilerde haber ve röportajlar yayınlanmaktadır.

Tablo 4. Çiftlikte izlenen tutundurma stratejileri

\begin{tabular}{|l|c|}
\hline \multicolumn{1}{|c|}{ STRATEJİLER } & n \\
\hline $\begin{array}{l}\text { Olanaklar ölçüsünde her türlü reklam, satış } \\
\text { tanıtım, halkla ilişkiler vb. faaliyetler } \\
\text { gerçekleştirilmektedir }\end{array}$ & 7 \\
\hline $\begin{array}{l}\text { Her yıl önceden belirlenen plana uygun olarak } \\
\text { her türlü tanıtım faaliyetleri } \\
\text { gerçekleştirilmektedir }\end{array}$ & 1 \\
\hline $\begin{array}{l}\text { Müssteri kayıtları incelenerek belirlenen müşteri } \\
\text { kitlesine uygun tanıtım faaliyetleri } \\
\text { gerçekleştirilmektedir }\end{array}$ & 6 \\
\hline Herhangi bir strateji izlenmemektedir & 3 \\
\hline \multicolumn{1}{|c|}{ TOPLAM } & 17 \\
\hline
\end{tabular}

\section{Halkla İlişkiler Çalışmaları}

Çiftlikler, halkla ilişkiler çalışmaları için ortak yöntemler kullanmaktadırlar. Araştımaya katılan çiftliklerin çoğu, anket seçeneklerinde bulunmayan yöntemler uyguladıklarını belirtmişler. Bazıları bölge halkıyla sık sık sohbetler yapmakta, bazıları çiftliğe ziyarete gelen misafirlerle kişisel diyaloglar gerçekleştirmektedir. Bazı çiftlikler ise daha kapsamlı çalışmalar yapmak amacıyla görsel, sosyal ve yazılı medyayı kullanmaktadır.

\section{Organik Ürün Pazarlaması Yapan Çiftlikler}

Çiftliklerin büyük bir kısmı aynı zamanda organik tarımla, organik üretim, ürün pazarlama ve satışı ile uğraşmaktadır. Anket sonucunda 17 çiftlikten 9'nun çiftlikte üretilen organik ürünlerin satışını yaptığı belirlenmiştir. Diğerleri ise satış yapmamakta, ürünlerini sadece çiftliğe gelen ziyaretçilere sunmaktadır. Çiftliklerden gelen yanıtlar incelendiğinde, ürünlerin satışı genellikle aynı yerlerde yapılmaktadır. Bu ürünler hem organik pazar yerlerinde, hem online kanallarla, hem de çiftlikte satışa sunulmaktadır. Bazı çiftliklerin İstanbul, İzmir, Ankara gibi büyük şehirlerdeki organik mağaza veya marketlerde ürünlerinin bulunduğu görülmektedir. Bu çiftlikler marka olmak yolunda ilerlemektedir. Bu durum, çiftliklerin başarılı pazarlama stratejileri 
uyguladıklarını, kaliteli ürün ürettiklerini ve sunduklarını, Türkiye'de organik tarıma, organik ürünlere, sağlıklı ürün tüketimine önem verildiğini göstermektedir.

\section{Ürünlerin Ekolojik Pazarlardaki Pazarlama Sorunları}

Çiftlik ürünlerinin pazarlanması ile ilgili en önemli sorunlar şunlardır: yoğun rekabet, tüketici tercihlerindeki hızlı değişim, pazarlama faaliyetlerinin çiftliğin mali yükünü arttırması, ürün farklılaştırma zorlukları. Organik pazarlarda yabanc1 markaların da var olduğu düşünüldüğünde, yerli markaların bu pazarlarda kendilerine yer edinmesi, tanınması uzun zaman almaktadir. Ancak son yıllarda Türkiye'de sağlıklı ve bilinçli tüketimin arttı̆̆ı, yerli organik üretimin geliştiği gerçeğini de göz önünde bulundurmak gerekir. Zengin doğal kaynaklara sahip bir ülke olarak organik yöntemlerle üretilen gıda tüketiminin artması sektörde rekabet ortamının artmasına neden olmaktadır. Çiftliklerin büyük bir kısmı pazarlama faaliyetlerine büyük yatırımlar yapmadıklarını ve pazarlama faaliyetlerinin çiftliğin mali yükünü artırdığını belirtmektedir. Çiftlikler misafir konaklamalarından pek fazla maddi gelir elde etmediklerinden dolayı, pazarlama ile ilgili harcamalarında da kisitlamalara gitmektedirler.

\section{İnsan Kaynakları Bölümünün Varlığı ve Personel Planlama Faaliyetleri}

Çiftliklerde çoğunluğukla insan kaynakları bölümü görevlerini çiftlik sahibi veya yöneticisi (14 çiftlikte) yürütmekte, ayrı bir insan kaynakları departmanı bulunmamaktadır. Çiftliklerin büyük bir kısmında (10 çiftlikte) personel planlaması yapılmamaktadır. Çiftlikler genellikle, aile çiftlikleri veya çok az personelle çalışan işletmeler olduğundan çiftlik yöneticileri insan kaynakları departmanının görevlerini kendileri üstlenmektedirler. Çiftlikte çalışan sayısı, çiftliklerin çoğunda, 10'u aşmadığı için personelin görevlendirilmesi, işe alımı ve yönetimi ile ilgili herhangi bir sorun yaşanmamaktadır.

\section{Yönetim Biçimi}

Anket çalışmasının uygulandığı 17 çiftlikten $14^{\prime}$ ü aile işletmesi olarak yönetilmektedir. Geriye kalanlarda sorumlu bir müdür olsa bile, çiftlik yönetiminde yine de çiftlik sahibi onunla birlikte, sorumluluk sahibidir. Anketi yantllayan çiftlik sahiplerinden bazıları, yönetimle ilgili herhangi bir sıkıntı yaşamadıklarını ve yönetimle ilgili herhangi birinin yardımına ihtiyaç duymadıklarını belirtmişlerdir.

\section{Personeli Yetkilendirme Düzeyi}

Çiftlikerin büyük bir kısmında (8 çiftlik) çiftlik personeli belirlenmiş ilkeler doğrultusunda kendi yetkilerini kullanarak karar vermektedir. Bu durum, yönetimle ilgili belirli bir düzenin ve herkes tarafından uyulması gereken kuralların olduğunu göstermektedir. Diğer çiftliklerde ise çalışanlar, karşılaştıkları sorunları üst yönetime (5 çiftlik) veya direkt olarak yöneticilerine (4 çiftlik) bildirerek yöneticilerin verdikleri emirler doğrultusunda hareket etmektedirler. Bu tür yönetim sisteminde yönetici olmadığ1 veya yoğun olduğu zamanlarda sorunların çözülmesi ile ilgili zorluklar yaşanabilmektedir. Ayrıca her çiftlikte iş bölümü olsa da gerektiğinde herkes birbirine 
yardım etmekte, birbirinin fikir ve düşüncelerini dinleyerek bu doğrultuda hareket etmektedir.

\section{Başvurulan Eğitim Kaynakları}

Tablo 5'te de görüldüğ̈̈ üzere çiftliklerin eğitim amacıyla başvurdukları kaynaklar genellikle "çiftlik içinde sağlanan eğitim faaliyetleridir". Bazı çiftlik yöneticileri bu kapsamda uzman yardımı aldıklarını da belirtmiştir. Çalışanların bölge halkından ve çiftçilerden oluştuğu göz önünde bulundurulursa, turistlere yaklaşım konusunda zaman zaman personel eğitimlerine ihtiyaç duyulması kaçınılmazdır. Çiftliğe gelen misafirler arasında aynı zamanda yabancı turistler de olduğundan çalışanların belirli seviyede yabancı dil bilmeleri gerekmektedir.

Tablo 5. Başvurulan Eğitim Kaynakları

\begin{tabular}{|l|c|}
\hline \multicolumn{1}{|c|}{ EĞITIM KAYNAKLARI } & n \\
\hline Çiftlik içi & 14 \\
\hline Dışardan sağlanan danışmanlık hizmetleri & - \\
\hline Uzmanlık yardımı & 3 \\
\hline Eğitim kurumları & - \\
\hline İş ve işçi bulma kurumu & - \\
\hline \multicolumn{1}{|c|}{ TOPLAM } & 17 \\
\hline
\end{tabular}

\section{SONUÇ ve ÖNERILER}

Çalışmadan elde edilen sonuçlar aşağıdaki şekilde özetlenebilir:

- TaTuTa projesi kapsamında faaliyet gösteren çiftliklerin çoğu ekolojik tarım yöntemlerinin uygulandığı, organik üretimin yapıldığı, çevreye karşı duyarlı ziyaretçilere ev sahipliği yapan, çeşitli ekoturizm faaliyetlerinin gerçekleştirildiği doğa dostu çiftlik-otellerdir. Çiftlikler, bulunduğu bölgenin doğal ve kültürel özelliğini taşımakta, bölgenin coğrafi ve yöresel özelliklerine uygun mimarisiyle dikkat çekmektedirler.

- Bazı çiftlikler, çiftlikte üretilen organik ürünleri aynı zamanda çiftliğe gelen misafirlere sunmaktadır. Araştırmaya katılan 17 çiftlikten 9'u çiftlikte üretilen ürünleri organik pazarlarda, mağazalarda, online internet kanallarında, aynı zamanda çiftlikte satışa sunmaktadır. Çiftlikler dağıtım kanalı olarak genelde internetten yararlanmakta aynı zamanda Genç Turla dağıtım amaçlı işbirlikleri bulunmaktadır.

- Büyük çoğunluğun hem gönüllü hem de misafir olarak ziyaretçi kabul ettiği çiftliklerde yapılan turizm aktiviteleri çiftliğe ek gelir kazandırmaktadır. Ancak elde edilen ek gelir, çiftliklerin toplam geliri içerisinde çok küçük bir miktardır. Çiftliklerde gerçekleştirilen turizm faaliyetleri turizmin mevsimsel özellikleri nedeniyle yılın belirli zamanlarında gerçekleştirilmektedir.

- Farklı kültürlerden gelen insanlarla sosyal ilişkilerin kurulması, yörenin doğal ve kültürel özelliklerinin tanıtılması, gönüllü misafirlerin çiftlik işlerine yardımcı olmaları bu çiftliklerin turizm faaliyeti gerçekleştirmelerinin önemli sebepleridir. 
- TaTuTa çiftliklerinde çiftlik turizmi kapsamında gerçekleştirilen aktiviteler kısıtlı olup yurt dışındaki çiftliklerde yapılan müzik ve hasat festivalleri, çeşitli davetler gibi özel etkinlikler veya çiftlik dışı faaliyetler bu çiftliklerde gerçekleştirilmemektedir.

- Çiftliklerin büyük bir kısmı aynı zamanda çiftlik-otel olarak faaliyet gösterse de çiftliklerde gerçekleştirilen insan kaynakları, halkla ilişkiler, pazarlama faaliyetleri aile işletmesi ölçeğinde yürütülmektedir. Örneğin, insan kaynakları bölümünün yönetim görevlerini yönetici veya çiftlik sahibi yerine getirmektedir. Yönetici/çiftlik sahibi aynı zamanda, hem çiftlik işlerine katılmakta, hem yönetim, hem personel alımını gerçekleştirmekte, personel için eğitim faaliyetleri düzenlemekte, hem de organik üretim ve ürün pazarlaması kararlarını almaktadır.

- TaTuTa çiftliklerinin dağıtım faaliyetleri kapsamında GençTur'la işbirlikleri bulunmaktadır. Çiftlik ziyaretinde bulunmak isteyenler, GençTur'dan bilgi ve destek alarak, ziyaretlerini bu acenta vasıtasıyla da gerçekleştirebilmektedir. Ayrıca çiftliklerde, reklam araçları olarak broşürler, fuarlara katılma, web siteleri de kullanılmaktadır.

- Çiftliklerin bir kısmında pazarlama faaliyetleri kapsamında her türlü reklam, satış, tanıtım, halkla ilişkiler vb. faaliyetlerin gerçekleştirildiği, bazılarında ise müşteri kayıtlarının incelenerek müşteri kitlelerine uygun tanıtım yöntemleri uygulandığı görülmektedir. Çiftliklerin kendi tutundurma stratejileri dışında, Buğday Derneği'nin iletişim kanallarında da (resmi site, sosyal medya, üyelere gönderilen "Ekolojik Yaşam Rehberi" adlı dergi) dönemsel tanıtımlar yapilmaktadir.

- Araştırmanın uygulandığı çiftliklerin halkla ilişkiler çalışmaları ise yöre halkı ile yapılan sohbetler, çiftliği ziyarete gelen misafirlerle gerçekleştirilen kişisel diyaloglar ve bu amaçla çiftliklerde gerçekleştirilen kişisel gelişim etkinlikleri vb. faaliyetlerdir. Bazı çiftlikler ise görsel, sosyal ve yazılı medyayı etkin bir şekilde kullanmaktadır.

- Organik ürün satışı yapan TaTuTa çiftlikleri ürünlerini organik pazarlarda, mağazalarda, online kanallarda ve çiftlikte gerçekleştirmektedirler. Bazı çiftliklerin Türkiye pazarında tanınan organik ürün markaları bulunmaktadır. $\mathrm{Bu}$ durum, hem çiftliklerin izledikleri başarılı pazarlama stratejilerini, kaliteli ürün üretimini ve sunumunu hem de ülkede organik tarımcllı̆ga, organik ürünlere, sağlıklı ürün tüketimine verilen önemi göstermektedir.

- Araştırmanın yapıldığ çiftlikler genellikle, aile işletmesi veya çok az personelle çalışan işletmeler olduğundan çiftliklerde insan kaynakları bölümü bulunmamakta, aynı zamanda çiftlik sahibi olan çiftlik yöneticileri insan kaynakları bölümünün görevlerini de üstlenmektedirler. İnsan kaynakları bölümünün olduğu bazı çiftliklerde de personel alımı zamanı genel müdür veya çiftlik sahibi, insan kaynakları bölümü veya ilgili bölüm müdürü ile birlikte karar verebilmektedir. 
Buğday Derneği'nin sosyal sorumluluk projesi kapsamında faaliyetlere, kurslara, etkinliklere ev sahipliği yapan bu çiftliklerin asıl amac1, üretim faaliyetlerinden ilk elden ekolojik yöntem, deneyim ve bilgileri paylaşmak, doğa dostu üretim ve tüketim modellerinin desteklenmesi yoluyla, toprak, hava ve su kalitesinin, biyolojik çeşitliliğin sağlıklı bir şekilde sürdürülmesine katkıda bulunmaktır.

Araştırma, kapsamında elde edilen bulgular doğrultusunda bu çiftliklerin gelişmesi için bazı önerilerin getirilmesi mümkündür. Bu öneriler aşağıdaki gibi siralanabilir:

a) Yerel ve ulusal yönetimlere yönelik öneriler;

- Doğal ve kültürel zenginliğe sahip kırsal alanlarda, çeşitli ekoturizm faaliyetlerinin gerçekleştirilmesi için bu bölgelerde bulunan çiftlikler ve çiftçiler organik tarım, çevre dostu sağlıklı üretim ve tüketim, sürdürülebilir turizm, ekoturizm faaliyetleri konusunda bilgilendirilmeli, bu tür faaliyette bulunmaları için yerel ve ulusal yönetimler tarafından desteklenmeli ve teşvik edilmelidir. Çiftlik turizminin gelişimi için yerel yönetimler ve merkezi yönetim birlikte çalışarak yerel girişimciliğin teşvik edilmesi için eğitim faaliyetleri düzenlenebilir ve teşvik programları devreye sokulabilir.

- Talep oluşturmak amaciyla, il sınırları içerisinde ya da çevre illerde bulunan eğitim kurumları ve sivil toplum kuruluşları ile işbirliği yaparak doğal yaşamı tanıtma vb. amaçlı organizasyonlar düzenlenebilir.

- Turizmde ulaşım oldukça önemlidir. Dolayısıyla iç bölgelere olan ulaşım olanaklarının iyileştirilmesine önem verilmelidir.

- Bölgesel markalaşma için yerel yönetimlerin desteği ile çalışmalar yapılmalıdır.

b) Çiftlik sahibi veya yöneticilere yönelik öneriler;

- Ziyaretçilerin çiftliklerle doğrudan bağlantı kurmaları konusunda problemler ve zorluklar yaşanmaması için çiftlikler kendine ait web siteleri, broşürler hazırlamalıdır. Ayrıca tanıtım broşürleri, videolar vb. hazırlanarak gerek geleneksel medyada gerekse sosyal medyada paylaşılmalıdır.

- Çiftliklerde yöresel yemeklerin tanıtımına katkıda bulunmak amacıyla yemek kursları düzenlenebilir.

- Buğday Derneği'nin “TaTuTa projesi” kapsamında belirlediği tutundurma stratejilerinin yanısıra, çiftlik turizmi yapan çiftlikler diğer destinasyonlardan farklı olan niteliklerini belirleyerek kendi stratejilerini geliştirebilir.

- Herhangi bir pazarlama faaliyetinde bulunmayan çiftliklerin öncelikli olarak iyi bir pazarlama planlaması çalışmasıyla yol haritası oluşturmaları gerekmektedir. Pazarlama planlamasında da ilk olarak yapılması gereken hedef pazarın belirlenmesidir (eğitim grupları, çocuklu aileler vb.).

- GençTur'un yanısıra, ayrıca diğer ulusal ve uluslararası seyahat acentaları ile de işbirliği sağlanabilir.

- Çiftliklerde insan kaynaları bölümü geliştirilerek personel alımında öncelikle yöre halkının kullanımına ağırlık verilmelidir. Bunun için bu bölgelerde nitelikli istihdam yaratacak bu çiftliklerde çalışacak olan yerel halka yönelik 
mesleki eğitimler sağlanmalıdır. Ayrıca, çeşitli bölgelerden stajyer veya gönüllü olarak gelen ziyaretçilerden çalışmaya ihtiyacı olanlara da iş imkanı sunulabilir.

\section{c) Araştırmacılara yönelik öneriler;}

- Çiftlik turizminin varlığının çok yönlü araştırmalarla ön plana çıkartılması gerekmektedir. Türkiye'de çiftlik turizmi, organik tarım faaliyetleri, organik tarım yöntemleri ve turizm aktivitelerinin birlikte gerçekleştirildiği çiftliklerle ilgili daha fazla araştırma yapılabilir. Çiftlik turizmi ve yerel halkın bu turizm çeşidine yönelik algıları ve tutumları, çalışanların beklentileri, müşteri beklentileri ve ürün ilişkisi gibi konular araştırılabilir Ayrıca, dünyadaki örneklerden de yararlanarak bu turizm çeşidinin geliştirilmesi ve tanıtılması amacıyla dergi, gazete yayınlarında, radyo, TV programlarında bu tanitımlara yer verilebilir.

- Uygulanan ptojeler, yapılan araştırmalar, yazılan makaleler, yüksek lisans veya doktora tezlerinin sonuçları çiftlik turizminin gelişebilmesi için çiftlik yöneticileri ve işletme yetkilileri ile paylaşılabilir. Yapılan bu çalışmada çiftlik yöneticileri bu taleplerini ifade etmişlerdir.

\section{KAYNAKÇA}

Ahmadova, S. (2015). Türkiye'de Organik Ekoturizm Çiftlikleri Üzerine Bir Araştırma. Istanbul: Yüksek Lisans Tezi.

Bulut, Y. ve Akpınar, E. (2010). Ülkemizde Alternatif Turizmin Bir Dalı Olan Ekoturizm Çeşitlerinin Bölgelere Göre Dağılımı ve Uygulama Alanları. III. Ulusal Karadeniz Ormancllık Kongresi (s. 1580-1590). Erzurum: Atatürk Üniv. Ziraat Fakültesi Peyzaj Mimarlığı Bolümü.

Civelek, M., Dalgın, T. \& Çeken, H. (2013). Sürdürülebilirlik Kapsamında Agro-Turizm ve Kırsal Kalkınma İlişkisi: Muğla Yöresindeki Tatuta Çiftliklerinin Agro-Turizm Potansiyeli Yönünden Değerlendirilmesi. Journal of Tourism and Gastronomy Studies, 2232.

Cut-Lupulescu, F., Dincu, A. M. \& Borlovan, I. C. (2014). Implications of Rural Tourism and Agritourism in Sustainable Rural Development. Animal Science and Biotechnologies, 301302.

Çinko, Ç. (2013). TaTuTa Projesi, çiftlik yaşamındaki hayatı şehir insanın yaşamıyla birleştiriyor. Mart 30, 2015 tarihinde Yeşilin Aslı: http://www.yesilinasli.com/2013/07/16/tatuta-projesiciftlik-yasamindaki-hayati-sehir-insanin-yasamiyla-birlestiriyor/ adresinden alındı.

Ersöz, S., \& Bozkurt, M. (2015). Kırsal Turizm Kapsamında Çiftlik Turizmi ve Rize İlinde Uygulanabilirliği. Journal of Recreation and Tourism Research, 1-9.

Gössling , S. \& Mattsson, S. (2002). Farm Tourism in Sweden: Structure, Growth and Characteristics. Scandinavian Journal of Hospitality and Tourism, 17-30.

Kim, B. R. (2010). Agri-Tourism And Its Internationalization Strategy. International Area Review, 8-11.

Kuter, N. \& Ünal, H. (2009). Sürdürülebilirlik Kapsamında Ekoturizmin Çevresel, Ekonomik ve Sosyo-Kültürel Etkileri. Kastamonu Üni., Orman Fakültesi Dergisi, 146-156. 
Oppermann, M. (1995). Holidays On The Farm: A Case Study. Journal of Travel Research, s. 63-72. Sima, E. (2007). Impact of Organic Farming Upon the Environment. Lucrari Stiintifice, Seria I, 2526.

Sünnetçioğlu, S. \& Yılmaz, B. (2015). İzmir'deki Restoran Yöneticilerinin Sürdürülebilir Restoran İşletmeciliği Üzerine Yaklaşımlarının Değerlendirilmesi. Karabük Üniversitesi Sosyal Bilimler Enstitüsü Dergisi, 94-114. 